\title{
The Meanings and Significances of Moses' Prayers in The Qur'an: From Tabari to Khazin
}

\author{
$1^{\text {st }}$ Moh. Anwar Syarifuddin ${ }^{1}, 2^{\text {nd }}$ Jauhar Azizy $^{1}$ \\ \{anwar.syarifuddin@uinjkt.ac.id ${ }^{1}$,jauhar.azizy@uinjkt.ac.id ${ }^{1}$ \\ UIN Syarif Hidayatullah, Faculty of Ushuluddin, Jakarta, Indonesia ${ }^{1}$
}

\begin{abstract}
This piece presents a new style of tafsir employing hermeneutical approach to interpret meanings as well as gaining significances of invocations uttered by prophets in the Quranic chronicles. To limit the study only on the chronicle of Moses, the prayers within the verses will be explicated by referring to famous tafsir literatures of Tabari and Khazin. Both tafsir respectively represent either the traditional (ma'thur) or a combined traditional-rational ( $\left.r a^{\prime} y i\right)$ interpretation to the Qur'anic verses. Highlighting the Israelite struggle against the tyrannical Pharaoh of Egypt, the chronicle of Moses as illustrated by some prayers invoked by Moses in several occasions is a journey of approaching God. It begins by true repentance from wrongdoing and consistent avoidance of sin, put man's trust in God only and preferring God more than any others. The chronic is certainly full of enriched meanings as we may take some lessons from historic events as well as bringing meaningful signification in some relevant messages along the course of hermeneutical task relating the gap between the past events and the recent problems of humanity.
\end{abstract}

Keywords: Qur'anic Studies, Hermeneutics of the Qur'an

\section{Introduction}

Efforts to discern the meanings of Qur'anic text in Islamic studies deal with various disciplines of knowledge including hermeneutics. As some philosophical disciplines were undergoing a new development after the Enlightenment in Europe, hermeneutics was not only then defined as theory of interpretation, but also a philosophical framework of criticism, where conditions of human understanding is being debated and disputed (Bleicher 1980: 1-2). At the crossroads, the vast arrays of Qur'anic studies have also similarly been dealing so many chronicles of the prophets in history. Within those chronicles, the powerless believers among the prophet's followers often called for their God to show His Majestic Power in order to overcome difficulties they were facing against their enemy. In such a situation, the Divine answer for the believer's call can be considered to be God's intervention to the human fate. A call or prayer invoked to God marks a penultimate human effort displaying their role as God's vicegerent on earth, as prayer is among the tools of human liberation.

More than merely dramas in human history, prayer invoked by prophets like Moses was identifies the prophet's closeness to God. There are a lot of meanings on what messages bestowed by such invocations, by then the query of this piece is how the recently modern hermeneutical theories explicate meanings of the Holy Scriptures, in additions to the generated significations of the interpreted Qur'anic verses? To limit the scope of study, this will only 
discuss invocations uttered by Moses, as the interpretation of the verses will rely on two books of tafsirs: The Jāmi 'al-Bayān fì Ay al-Qur'ān by Ibn Jarīr al-Thabarī (d. $241 \mathrm{AH}$ ) and Lubāb al-Ta'wīl fì Ma 'ānī al-Tanzīl by 'Alī bin Muḥammad bin Ibrāhīm al-Syaiḥi famous for the epithet al-Khāzin (d. 1341 AD.) Both represent works of tafsir in between classical Islam and its Middle Ages as both also employ many traditional accounts (riwaya $\bar{a} t$ ), in addition to the distinctly rational embodiment in the latter's interpretation. In explicating the meanings of the Qur'an both tafsirs were rich of the contested meanings, which may be the same or even differ at the same time that be quite attractive to discuss.

In addition to reconstruct meanings, the task of interpretation in hermeneutical approach is to regain meaningfulness of the old texts for the recent readers nowadays. This research tries to construct a reconciliatory product of interpretation, i.e. by not only stressing upon a reconstructive meaning for the verses of the Holy Book in order to be in accordance with the intention of the Speaker of the Text, namely God, but also to enliven the meaning of divine messages in forms of recent significance for the present readers. Hermeneutics in this article is to refer its generic meaning concerning the theory of interpretation. Thus, there should be a distinction between meanings and significances as referring to the hermeneutics of E.D Hirsch Jr., in which meaning is the verbal sense aimed by the author, whereas significance is meant to be its meaningfulness for the readers nowadays. From this hermeneutical point of view, according Hirsch, the verbal meaning is attached to the word as it was unchanged, whereas significance will always change in accordance to secondary elements attached to it like the subjects, situations, as well as concepts (See Hirsch 1967: 8; Palmer 1969: 61.

In addition to E.D. Hirsch's theory of interpretation, this research also apply several theses promulgated by Richard E. Palmer in his hermeneutical manifesto in moderating gaps between the understanding of the followers of objective hermeneutics like Emilio Betti or Hirsch and the subjective hermeneutics like Gadamer's dialectic or the followers of the New Hermeneutic that can be mediated in Palmer's manifesto among his 30 thesis on hermeneutics, Palmer underlined his notion on "hermeneutical experience" stressing the need of historical awareness in literary interpretation. He said that literature has internally been historical, by which the task of interpretation is to bridge the distance in history. The aim of Palmer is to bridge distance in history in between the two opposing perspectives: between the formalists in one hand and the antiquarian in the other hand within the American literary criticism (Palmer 1969: 250)

In line with Gadamer, Palmer also underlined that to understand literature one should refer to a point of view historically formulated by himself and his world. Here, forms of intentions, pre-concepts, and point of views perceived by someone were certainly inherited from his past. Therefore, one in reality moves and exists in the world that was historically formed by his-own understanding. If he then reads a literary work, it will present an "other" world, which is not completely discorded from the world where he belongs to. However, in order to experience the composition of the work, one has to find his own understanding deeply. By such a way, he will always escalate his historically formed understanding. Reading a literary work according to Palmer is to historically experience it.

If Palmer underlined his hermeneutical manifesto as criticism to American literature, then we can bring it to enrich aplications in interpreting Quranic chronicles in between its scripturalist approach and as well as the substantialist approach that reduces its meaning as merely part of historical romanticism of the past. It is time now to construct a new method of interpretation by way of seeking the objectively valid meaning as desired by the Speaker as well as to dialoge those meanings within the dynamics of its historical situation at times being correlated to the readers' horizon at present. 


\section{Result and Discussion}

The entire chronicle of Moses and his followers among the Israelites as mentioned by the Qur'an can be conceived to be the struggle of the Israelites from the tyrannical Pharaoh of Egypt, but God is the only Helper. We can see such a mystical significance from about five invocations uttered by Moses in several occasions from his mature age to his old era.

\subsection{The Wrongdoing and Sinfully Satanic Deed}

The story begins when Moses was mistakenly killed a young Egyptian in Memphis as he then was chased by the army. There are two invocations here. In QS. 28:16 a prayer was

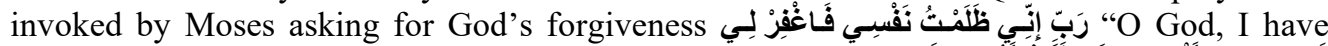

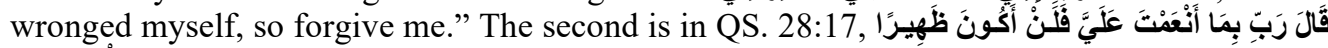
اللْنُجْرِِمِينَ Moses said, "O my Lord, for the favour which You have bestowed upon me, I will never be a helper to those who sin.

In order to clearly discern what had happened in the story, we can trace the backgrounds of the chronicle from QS. 28:14-15 explicating that Moses punched a young Egyptian as he was helping an Israelite in a quarrel. As he hit the youth, the boy died. At that moment, Moses immediately realized that he had committed an error. Such an awareness of committing an error arises instantly from within due to the wisdom and knowledge he had possessed at the age of maturity. It is the wisdom and knowledge also that guides his actions to ask forgiveness from God when he committed the mistakes. In this case, by asking for divine forgiveness, Tabarī comes to a conclusion that at that age Moses had attained wisdom and knowledge as his body had also grew strong when he reach the end of his young age (syabāb) identified by the perfection of character and capability to think. According to Tabarī, there were differing interpretions in guessing how old Moses was at the time of the incident. Some commentators say that spiritual maturity will be achieved at the age of 40 , while the physical maturity of mankind is reached at the age of 33. Tabarī then concluded that what is meant by the attainment of wisdom and knowledge is as someone realized the important position of religion as well as Divine insight (ma'rifah). However, Tabarī is more inclined to assess the physical and intellectual maturity that had been achieved by Moses as the capability to understand law (fiqh) and the maturity of reason before the statute of prophecy (qabla nubuwwah). Hence, the sentence which marks the end of QS 28:14, "And thus we reward those who do good" according to Tabari as clearly referring to Moses' good reputation by his acquisition of wisdom and knowledge before God appoints him as a Prophet (Tabari 2000: xix, 535-536).

Khāzin had fully agreed with Țabarī, but he slightly had different opinion on a minimum limit of maturity. He said that maturity begins as someone reached the age of 18 years, so for Moses in his age of 33 years was the final limit. He continued his explanation that the name of the city that Moses entered was Memphis (Arabic minf) which was in the territory of Egypt. Besides, there are also two other alternate opinions on the name of the city as Khāzin refers to either the city of the sun (shams) or Hābīn, a village which is 2 farsakhs away from nowadays Cairo. According to Khazin, the occasion happened at "the time when the inhabitants were caught off guard" interpreted as "noon", when almost all inhabitants were in a nap (qailūlah) (Khazin 1995: iii, 359).

By the prayers Moses asked God for his "forgiveness" that could also mean that God "covered up" (yasturu) Moses' wrongdoing. The term "Allah forgives Moses" is interpreted by Khāzin as "God covered up [the news of the murder] so it was not known by Fir'aun who the killer was". Khazin spesifically mentioned "blessing" that Allah has bestowed on Moses by the favour of "forgiveness" (maghfirah) as God covers (the news) about his actions that 
have killed a young Coptic man. Furthermore at the next day he was asked for the second time for helping the same Israelite for the same wrongdoing, Moses was so determined to object that he did not want to help sinfully satanic acts. According to Khazin, the second prayer is a sign that the Israeli friend whom he helped the day before would have turned out to be apart from the group of people who truly believe in God because of his habit of committing sins (Khazin 1995: iii, 360).

Among the significances of the prayer is that God certainly forgive Moses as clearly stated at the end of QS 28:16, "...Allah forgave him, for surely Allah is Forgiving, Merciful". Consequently, forgiveness given to Moses that means that his sin had been covered up by God should be accompanied by consistent efforts to avoid repeating the similar mistakes in the future. The verse shows that Moses' repentance was being tested. Acknowledging mistakes and asking for Divine forgiveness will be meaningless without a determination to repent, by not repeating further sins in later periods. From here the consistency of repentance is truly conducted sincerely, being tested its consistency, as well as asking for further blessing as Allah erases the record of the committed sin. We may imitate Moses' praying by asking forgiveness from God, beginning with the recognition of having made a mistake accompanied by a sense of remorse that the wrongdoing that was done also became a tyranny committed against himself, so then to correct the next step someone is determined not to make the mistake in the next period is a guide in practicing true repentance.

\subsection{From True Repentant to Trust God}

The saga continues. In QS 28: 21 it depicts a prayer evoked by Moses when he was forced to go out of Egypt to avoid the pursuit of those who wanted to capture him. An escape was suggested by a man, whom Tabari called Sham'ūn or Sam'ān, while Khazin added an alternate third name Hazqīl in interpreting the phrase mentined by wa jā'a rajul-un min aqșa $l$ madinat-i yas'ā (someone who came rushing from the edge of the city). Khāzin interpreted the man as one of the Israelis who served as a trusted employee of the family of Pharaoh (see Tabari 2000: xix, 547; Khazin 1995: iii, 361). Such a suggestion might have been considered as the man's loyalty to Moses as he was certainly raised in Pharaoh's palace since he was born and washed away into the Nile as the baby Moses was finally found by the wife of Pharaoh. Thanks to the advice given by this person, Moses then fled out of Egypt heading to Madyan.

For Moses, the escape to Madyan was so frightening as nobody he could trust. In fact, he could only rely his hope in God so that he would be saved from those who wanted to persecute

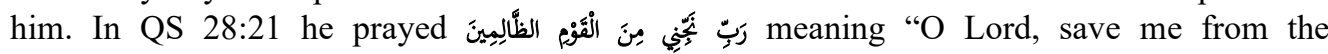
wrongdoers." Tabarī interestingly interpreted the prayer as Moses hoped, "O Lord, save me from those who disbelieve, who did wrong by themselves with their disbelief in You." At this time, Khāzin also agreed with Tabarī that the wrongdoers are considered as a group of infidels.

Moses' good attitude as well as his choice to rely only onto God that he made God as the foundation of hope is a manifestation of act of resigning. When he feels there is no human who can be trusted to provide help for the problems he faces, then he chooses to ask for help from Allah SWT. He pleaded with God for peace, while at the same time asking for His salvation to be kept away from the wrongdoers as being captured was a risk that must be taken by Moses when the news about his mistakenly beating a Coptic to death was spread up to the entire Egypt.

By putting the only reliance in God, then Moses posed his fourth prayer while heading to

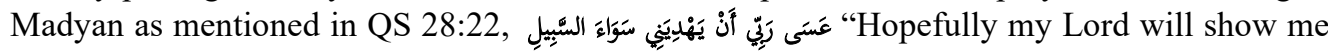


the right path." Fear of a group of people who will do wrong or a feeling of confusion to determine the purpose of what will be done had made Moses always ask for guidance from God only. This was proven when he decided to flee towards the city of Madyan. According to Khāzin, the city of Madyan was chosen by Moses because there was a descendant of Abraham's family, where Moses himself was one among descendants of the Abrahamic children. The city is named after its founder Madyan b. Ibrahim. Travel distance between Egypt and Madyan can be reached more or less within eight days travellin on foot (Khazin 1995: iii, 361). In a state of worry over the pursuit of the ruling Egyptian army, Moses fled out of Egypt with no vehicle ( $z a h r)$, no provisions ( $z \bar{a} d)$, and none accompanying him to escort the right direction. Accordingly Moses only ate leaves from trees and plants that grew on the earth, so that the greenish color in his stomach was clearly visible. Arriving in Madyan, even his foot seemed almost dislodged (Khāzin 1995: iii, 361; Tabarī 2000: xix, 550). According to Khāzin, based on the history of Ibn 'Abbās, that was the beginning of the trials that God gave to Moses, so it was not surprising that he did not stop asking for God's guidance and help.

It was all the way to Madyan that Moses was endlessly pleading for God's guidance to be given the right direction. The prayer in QS 28:22, "May my Lord show me the right path" is a reflection of his hope to be directed to the right path to Madyan. He really did not know the direction of the road to Madyan. In fact, Khāzin recounts here, that after Moses prayed for guidance from God, an angel was sent to accompany him with a goat ('anzah) in his hand, so he went with the angle to Madyan. Here, God's guidance is important, a determining factor that can give peace to Moses during his flight, so he can finally get to the city of Madyan. Allah's guidance is also needed so that he can take the right path at the right time, so that he does not encounter any other obstacles.

Reflecting on the story of Moses who always asked Allah for guidance during the plight to Madyan as represented by his prayers, while still trying as hard as he had to do, someone can imitate also to expect the pursue of better conditions, when he steps up forward to improve himself while moving from the difficulties he is facing. We could alos signify the prayer that even if in recent days one has to start a new reality of life from the very beginning after recovering from a disaster, then by relying all problems onto God and asking for His guidance, the hope that is anchored in prayer for God's guidance is a very useful motivation. Prayers asking for guidance become encouragement for anybody in all of efforts he had made tirelessly. The combination of the two is a good start for achieving the expected reality that God will give him a better replacement in his new life.

\subsection{God the Ultimate Helper}

The jouney taken by Moses continued as he arrived at Madyan savely. In QS. 28: 24 it is depicted a prayer evoked by Moses as he arrived at the suburbs of Madyan. As he took refuge in the shade after helping two shepherd women drinking her sheep. Moses uttered his plea,

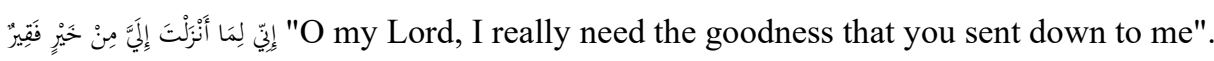

It is not certain whether Moses hoped for gratitude when he had finished helping the two shepherd women. In QS 28: 23 it was beautifully illustrated the uniqueness of the events that occurred, when Moses looked far behind the shepherds of men who were busy drinking their livestock. At far there were two women busy for blocking their own livestock. Moses then asked why the two did this. Moses also received an answer that the two women could only drink their livestock after the shepherd's men returned home. It turned out that the two women were replacing their elderly father, herding their cattle. There are three opinions about the interpretation of who is the father of the two shepherd women in Khāzin's perspective. First, 
he was Shu'aib AS himself; second: Bīrūn, son of Shu'aib's brother, because Shu'aib died not long after his eyes became blind; and third: one of the followers who believed in Shu'aib (Khāzin 1995: iii, 361).

After hearing the story, Moses also helped the two women. Khāzin detailed a number of explanations of what assistance was given by Moses to drink the livestock belonged to the two women. There are three different opinions expressed by Khazin without mentioning any sources. First, Moses placed pity and pity on the two women, so that suddenly a large stone that could only be lifted around ten men and closed another wellbore near the two women's positions shifted to create a new well gap, so that both could drink cattle their breeders. Second, Moses went ahead and competed with other herdsmen and then imitated their way to drink the animals of the two women. Third, it is said that when they finished drinking their livestock, the shepherds of the men covered the well with large stones that only ten people could lift. So Moses came and lifted the stone, and with only the blessing of one bucket of water, he gave all the two animals their livestock drink (Khāzin 1995: iii, 361). Of the three versions of the commentary put forward by Khazin, all of them indicate attempts conducted by Moses to help the two shepherds getting their animals drinking. As a result, there is no need to wait in the afternoon after all the male herders have finished drinking their sheep, the two women were able to go home earlier than usual. While Moses sought after a place to take shelter under a tree called samurah (Khāzin 1995: iii, 361), by which he hope for food or any kinds of goodness to overcome his starving stomach.

Both Tabari and Khazin agreed to interpret the "goodness" (khayr) that Moses needed in his prayer to mean "food". This is in accordance with the condition that Moses was in a state of fear and hungry when he arrived at Madyan. Conditions of fear led Moses not to ask for help from his fellow humans, but chose to ask him only to God. Moses' prayer asking for the descent of food was heard by God and not long being answered. In QS 28: 25 it is clearly stated that one of the two women came back to see Moses. She walked shyly as she said: "Verily, my father has called you, so that he will grant (your) goodness that Moses gave to drinking their livestocks. So when Moses came to his father (Shu'aib) and told him a story (about him and his plight, Shu'aib said: "Do not be afraid, you have survived from those who do wrong".

Moses' sincerity helped the two shepherd women by drinking their goats, allowing the two women to go home faster. This invited their father's question, so the father then asked one of his daughters to bring Moses who had helped them to be treated at their home. When he arrived at Shu'aib's home and was asked to enjoy a meal. Moses initially refused the meal because he did not want the help he had been given paid. But the father explained that it was indeed their custom to entertain guests coming to their homes by giving them food and drink. Moses then enjoyed the meal provided. Such a meal and family protection given by Shu'aib seemed to be the right answer to Moses' prayers needed not only for food, but also the goodness of his future life. By Shu'aib Moses was offered a better job and living conditions, when he was appointed as Shu'aib's son-in-law to one of his daughters.

There are some significance from the above story teaching that we cannot limit the goodness suited for someone. Goodness finally obtained by Moses during his escape to Madyan was the result of all the requests he made to God. By granting Moses' requests, God has outlined so much good for Moses in knitting his new destiny in his country of escape. He survived the pursuit of Pharaoh's army who could not reach Madyan because it was outside his authority, and there he found a new family that gave him the opportunity to build a family, before he returned to Egypt to carry out the obligation of preaching as an apostle to the Israelites at a later time. For any reader nowadays, such a prayer is certainly relevant for 
anyone who wants to emulate Moses' example by risking all his hopes on God, as the only Essence he believes in, even for something of a physical nature. Evidently, by making God as the main support for expectations in the face of difficulties in order to be free from wrongdoers who bear fruit in the acquisition of goodness that is not only in accordance with his expectations, even better, God knows the best of mankind.

\subsection{Returning Back to Egypt as the Israelite Leader}

Moses spent about twenty-eight years on his running away in Madyan. He served ten years as the shepherd of the Shu'aib's family as well as marrying one of his daughters named Șafūrā', with whom he built his family for other eighteen years there. In the middle of a returning journey to Egypt with hs family Moses was appointed to be the apostle for the Children of Israel. In QS 20: 25-28 Moses evoke some prayers as God sent him to preach

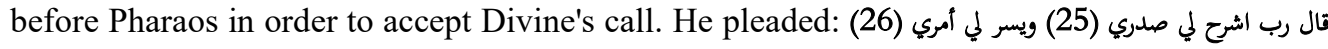

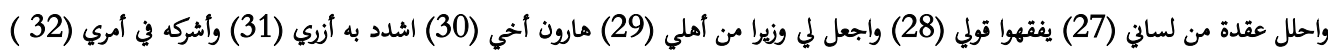

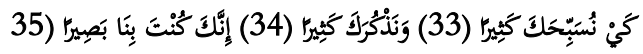

(25) Moses said: "O my Lord, extend to me my bosom, (26) and make it easy for me, (27) and release stiffness from my tongue, (28) so they understand my words, (29) and Make me a maid of my family, (30) (i.e.) Aaron, my brother, (31) confirm with him my strength, (32) and make him an ally in my business, (33) so that we will glorify You much, (34) and remember you a lot. (35) Verily, You are our All-seeing."

The list of Moses' requests in his prayer this time is quite long, different from the previous prayers during his escape to Madyan, which was generally quite short, situational, and practical. This prayer also bears a manifestation of his trust to Allah, when he only refers to Allah as the only place of asking for help to unravel difficulties. It was God who commanded Moses to preach Pharaoh, so it was to Allah that he call for necessities and help needed. Moses relied his problems only to Allah in order to obtain stability and a broad chest, so that he could gain confidence to dispel his fear of Pharaoh along with his army. He realized that God will help as long as he also helps God.

Among many things Moses had to prepare during his journey back to Egypt was the enrichment of his mental strengths. The first thing that Moses asked for was the spacious chest, by which things would turn to be easier. Khazin stressed his explanation that spacious chest requested by Moses means his spaciousness for the truth, because Moses had a great fear of Pharaoh. He was so afraid of Pharaoh's bad temper and many of his soldiers. According to Khāzin, by pleading for divine grace to broad his chest, Moses realized that none would actually harm him harm except by God's permission.

It can be discerned here that returning to Egypt and seeing Pharaoh ignited little fear in Moses only as he remember to his memories before escaping to Madyan. Moses knew very well that Pharaoh had a bad temper that brings his habit to be easily angry. The great number of his troops also belittled Moses in terms of his personal confidence. However, his escape to Madyan taught him many lessons in facing many difficulties by way of reliance to God only. Hence, he begged God to give him a broad heart, so that he could accept the truth of his appointment as an apostle, by which he received the command to preach Pharaoh in full of God's support to his new task. Here, both Țabarī and Khāzin agreed that Moses indeed requested convenience of carrying out the da'wah obligations which were imposed on his shoulders.

In additions, Moses also begged God to give him fluency in speaking. Moses' speech was bad because his tongue was slightly tough as he put embers into his mouth that burn his 
tongue at his childhood. Khāzin recounted the story of Moses' burnt tongue along with the story of Moses' mischief while he was within the family of Pharaoh. It is said that one day little Moses hit the head of Pharaoh and pulled his beard. Such a mischief has angered Pharaoh. Moses' insolent attitude made Pharaoh think that Moses was truly his enemy haunting him in his dreams. At that time, Pharaoh even accused Moses of wanting to kill him. Pharaoh prepared punishment, but only after his wife Asiyah defended Moses' delinquency as only ignorant child whose minds were still imperfect. In fact, a little boy like Moses at that time had not yet understood the true nature of things. Hence, when Moses was offered two things between jewels and coals, Moses chose the coals, not the jewels, as he then put the burning embers into his mouth. In this prayer Moses asked God to heal his tongue in order to speak fluently. Tabarī concluded that Moses' tongue was healed as the prayer in QS. 20:36 marks an end of the story, when God confirmed that Moses had granted what he asked for (Tabari 2000: xvi, 56).

However, his tough tongue was also the reason why Moses asked his brother Aaron (Arabic: Hārūn) to company him visiting Pharaoh. Hence, had God granted him healing his tough tongue, God also ordered Aaron to company him visiting Pharaoh. There are several reasons mentioned by Khazin when Moses chose to be accompanied by Aaron in carrying out his missionary mission to face Pharaoh. According to Khazin, Aaron was older than Moses, more eloquent, more handsome and taller. These reasons led Moses to ask God to be accompanied by Aaron in preaching before Pharaoh.

Tabarī mentions the story from Ibn 'Abbās citing that Aaron was indeed older than Moses. Tabari also added that Moses needed Aaron not only as his representative (wazīr), but that Aaron was also needed by Moses to be his translator. In the expression of his prayer in verse 31, Moses emphasized that Aaron could help him before Pharaoh. In addition, in his prayer, Moses also wanted that he could be more intensive in worshiping with Aaron, when he asserted that with his brother he could more glorify and recite (verses 33 and 34). And more importantly, Moses stressed again that he did not ask for making it up, because all things he requested were certainly known by God.

Commenting to QS 20:36, "Allah said:" Verily your request has been permitted, O Moses." Khāzin explained its meaning that God has granted all of Moses' requests. In line with Khāzin, Tabarī in the interpretation of this verse even specifies that God has granted all requested by Moses, starting from expanding his chest, facilitating his affairs, eliminating the glitch of his tongue, making Aaron a vizier, establishing his strength in the presence of Aaron, and the participation of Aaron in their apostolic affairs altogether.

When he was appointed to be an apostle and received the order to meet Pharaoh as well as preached him to call him to the path of monotheism, Moses thought that logically the command was quite difficult to realize. Therefore, Moses' requested God to grant several things he needed as he also realizes that God is his only helper, just as when he faces difficulties God had also help him. Thus, he must undergo his task to go back to Egypt.

In addition to strife, praying is a basic step for a servant as one faces difficulties. By evoking prayers to God, one is relying on his own efforts and strength alone into divine Hands. Calculating the power of self in carrying out the mission charged by Allah to the Apostle is the best step and strategy. While asking God for help is a logical consequence because the order came from Allah and for the sake of Him Almighty. Allah sees the conditions of His servants, the requests posed to God expect that God removes obstacles; hence, one's request in a prayer is naturally made, as then it becomes requirement of success. Here, praying for spaciousness and ease is a good step to start a mission hoping that God will facilitate the doer to achieve his goal. 
In daily practice, the prayers expressed by Moses are often said at the beginning of a conversation or sermon hoping that the speaker can speak fluently, so that his explanation can be captured properly by the listeners. The aspect of eloquence that is always wanted by those who want to speak becomes very important, in addition to being a supporter of the success of the results of talks, lectures, negotiations, and other forums of discussion. On the other hand, spaciousness is also needed so that someone can understand the truth of God's commands and then digest them by asking for help only from God to achieve them.

This prayer is also often evoked by students starting their learning process, as the broadness of heart and broad heart is a good sign for the inclusion of the process of transfer of knowledge in the learning process (ta'lim). Here, spacious and broader heart as well as peace of mind is demanded so that the learning process can be followed more easily to achieve the desired target in the end. Usually, student mix the prayer to that was requested by Muhammad that Allah may add his knowledge in understanding the Qur'an (QS. 20: 144).

\subsection{Moses Prefers God to His People}

The result of the call for Pharaohs was not quite satisfactory as he refused to accept God the One. However, Moses and his followers were saved by God from the chase of Pharaohs and his army by the split of the Red Sea providing 12 paths for each of the Israelite clans. Unfortunately, Moses was not so pleased by his people's obedient to Divine order. In QS. 5: 25 Moses finally asked for separation from his people, as they were reluctant to fulfill God's command to enter the promised holy land (al-ard al-muqaddasah). The reason was simply that they did not want to fight against the inhabitants of the city, i.e. the violent rulers of the

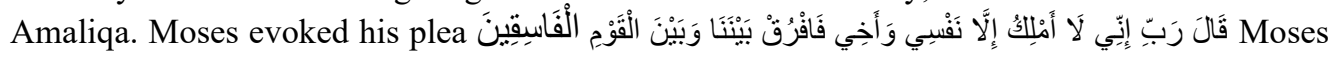
said: "O my Lord, I do not rule except myself and my brother, so separate us from those who are defiantly disobedient."

The background to the prayer request revealed in the story of Moses began with the descent of Divine command to the Children of Israel who had just survived the pursuit of the Pharaoh's army by crossing the Red Sea in order to go to the promised holy land. In QS alMā'idah 5: 21 it is stated that Moses said, "O my people, enter the holy land which God has appointed for you, and do not run away (for the fear of the enemies), then you will be the losers." This divine order was rejected by the Israelites because of their fear of the enemy, so they are reluctant to fight.

The first question that must be discussed here is which country is meant as the holy land that God established for the Children of Israel? Tabarī cited the history of Mujahid from Ibn 'Abbās and said that the holy land of the Israelites was Mount Sinai and its surroundings. While according to the Qatādah, the country is Palestine. Some Tabi'īn also argue that the country in question is the land of Arịhā. There are also those who consider the promised holy land is the land of the city of Damascus, the country of Palestine, and parts of Jordan, as blessed places.

Meanwhile, aside from places previously mentioned by Tabarī, Khāzin expresses his own interpretation as he found within the Scriptures (the Torah) that Shām region is one of the treasures of God, many servants of God settled in it, which God had also ordained for the Children of Israel. Khāzin explained that in the Preserved Tablet (Lauh Mahfuz), there had been determined that the land was for the Children of Israel to live on the soil. Allah has commanded the Children of Israel to enter this land and inhabit it. However, Khāzin asserted that this promise requires obedience, so that when the conditions proposed were not fulfilled due to their rejection, they too had actually lost the right to inhabit the place. 
In fact, it has been warned in QS 5:21 that the Israelites refused the Lord's command to enter the promised holy land, because of their fear of the cruel ruler who controlled the land. In QS. 5:22-24, it is stated, (22) They said: "O Moses, verily in that land there are people who are brave; in fact we will never enter before they come out. If they come out, we will definitely enter it." (23) Two people among those who were afraid (of Allah) that Allah had blessed them both: "Invade them through the city gate, so if you enter it surely you will win, and only in Allah should you put your trust, if you are truly a believer." (24) They said: "O Moses, we will not enter it once and for all, while they are in it, so go with your Lord, and fight both of you. Surely we are just sitting here waiting."

The explanation to the series of verses above confirms the strong refusal of the people of Moses to enter the promised holy land, because they are really reluctant to fight to seize the city. They were so afraid of the mighty people who controlled the city, that almost all of his people refused to fight for the promised territory. Khāzin interpreted that the jabbārin who controlled the city were ruthless and cruel rulers, big and strong. They are the Amaliqa tribe, from the remnants of 'Ad. Even the advice of two of them, interpreted as two of Moses 'followers named Yūsha' bin Nūn and Kālib bin Yāfinā - who suggested a strategy of attacking together through the gates of the main city as they were being armed with Allah's help--- was later rejected outrightly by almost all followers of Moses at that time. Khazin explained that the two representatives of Moses' messenger were reminded of the promise of the coming of Allah's help, and that God would not forget his promise. But they did not want to go to war and enter the city forever. They preferred to sit and wait while allowing Moses to go to war along with God.

In the midst of despair Moses persuaded the Israelites to fight in order to enter the promised Holy land. The prayer is certainly an expression of Moses' anger towards the reluctance of his people to obey God's commands. This prayer was at the same time a reflection of Moses' resignation by submitting his disappointment to the attitude of his people to the decision of God who gave the order. When his people were reluctant to carry out divine command, then Moses returned the problem to God in order to punish his people. Moses assumed that the rejection was and act of disobedience (fasiq), to which Khāzin defined it as an action that came out of obedience to God's commands. Moses insisted that he now only had himself and his brother, because he had separated himself from his people, when he asked to be separated from followers who did not obey the commands of Allah. In fact, an apostolic task is reaching its end when the Apostle completes the call, but the people refuse to accept the message. Concerning the results and the continuation of fate for those who do not want to accept the appeal it is fully returned to God only.

This prayer became an expression of Moses' inability to determine the outcome of da'wa. Tabarī explained that the phrase Moses who called himself no longer possessed anything other than himself and his brother means "I can no longer afford anything other than [what has been sought]." Meanwhile, Moses gave his affairs completely to God. According to Tabarī, the phrase means, "separate us and them by [completely surrender to] your decision, which you will give to us and them, keep them away from us." In contrast to Tabarī, Khazin prefers the meaning of separation ( ir $\bar{a} q)$ that Moses asked for from his people with the phrase "ahkum" means "a decrease in punishment" or "punish" and "decide" between us and them. This meaning confirms that Moses gave the ending of his apostolic task a cry by submitting a decision on acceptance or rejection merely to God only, as the One who gave the command.

The prayer was the penultimate anger posed by Moses to his followers, when the Israelites were considered to go against God's will. They had also doubted Yusha' and Kālib's strategy to attack the city that incited more anger from Moses. The prayer asking for 
separation from those who disobeyed the commands of God and His Apostles are often put forward by some other Apostles. The Qur'an illustrates the other ones done by Shu'aib (QS 7: 89), Sālih (QS 23:29) or even Muhammad (QS 21:112) when his own people did not want to follow his call.

The essential request that apostles asking God to be separated from his people, as was the case here with Moses was because the prophetic mission had almost reached an end of their patience. When the positive results gained, the Apostles succeed performing their missions, but when the apostolic mission were rejected by their people, the apostles then handed over the matter to God as the Giver of the command. Here, the deadline for being patience to wait for the results of the call is expired, so then they ask God that they should be separated from dissident groups fearing that those dissident group would have been severely punished, hence they had to seek to avoid themselves from such a bad punishment.

As Moses' call to enter the promised holy land was rejected by the Israelites, God thrn forbid them from entering the city for about forty years, as said at the end of this story, "Allah said:" (If so), then surely the country was forbidden for them for forty years, as they will revolve around earth (QS 5:26).

Tabarī explained that with this prohibition the Children of Israel were forbidden to enter their holy land for 40 years. He also explained that it was only after the passing of the 40 year that Allah later won the holy land for Israelites, so that they could settle in the city. Some of the Israelites died after twenty years of suspension, and only their children who were born later were allowed to enter the city. Tabari notes that the victory of Israelites was obtained after some of them, such as Yūsha' and Kālib, and other Israelites succeeded in combating the evil rulers of their holy land.

Khāzin has his own explanation regarding the punishment for the Israelites. For him, the prohibition of entering the holy land meant a command for the Children of Israel who ignored God's prohibition to live freely for 40 years facing all kinds of difficulties and hardships as their punishment and trials (mihnah). Such punishment was given to 600,000 Israelites who did not want to fight, excluding Moses, Aaron, Yūsha' and Kālib because, according to Khazin, Allah made it easy for them as God made it easy for Abraham when it was burned by making the fire cold so that Ibrahim was saved.

The signification of the prayer of Moses asking for separation from his people who disobeyed God was truly apostolic attitude by way of surrendering the result of a mission to God alone. Thus, separation from his own people is generally requested by any Apostles feeling that they could not resist from any destruction due to the coming of punishment for the sinners. Such a prayer is relevant to anyone who wants to complain to God about the difficulties encountered along the way of calling for the path of God due to the limitations of power and efforts to achieve the desired missionary success. Like Moses who has no ability other than himself and his brother, then there may be among the spreaders of the message of God on this earth who experience a similarly difficult situation to what Moses and Aaron had experienced. As the final part of the da'wah should be relied on God, separation from people who disobeyed should be chosen as the final solution when unity in a state of mutual faith cannot be achieved. By returning the affairs to God, the path of separation also becomes a form of resignation to God as the origin of the command.

However, the momentum for proposing the "parting ways" is not the end of the da'wah process. Șâlih and Shu'aib continued their obedience with the faithful after the destruction of their deniers among their people. Likewise Moses and a few devout followers continued their live approaching the promised Holy land until their death. In the case of the prayer of the Prophet Muhammad who asked to be separated from the Quraysh at the end of the da'wah 
period in Mecca, he was even instructed to emigrate and start a new success in Medina. Therefore, it is clear that the way of separation is the solution that should be requested for the stagnation of da'wah to end the jammed process of da'wah and its difficulties after all of the effort is expended. The path of separation can be a vehicle that enables the consolidation of the power of truth for the process of further propagation in another place that is better, so that the success of da'wah can ultimately be achieved.

\section{Conclusion}

The conslusion of this piece shows that in all human life, there is always God's intervention. When humans have tried and made use of all their effort to struggle, in the end the submitted alll the results to God, namely by way of evoking prayer to God. Man pray as he was aware that he is a weak creature, had expecting God's intervention. This happened in the story of Moses. As a prophet, in his prayer Moses' asked God to help him carry out mission. Divine intervention is a must in the believers' life.

Acknowledgements. This research supported by UIN Syarif Hidayatullah Conference Grant for ICONQUHAS 2019

\section{References}

[1] Bleicher, J.: Contemporary Hermeneutics: Hermeneutics as method, philosophy, and critique. London: Routlege and Kegan Paul. (1980)

[2] Hirsch, E.D. Jr.: Validity in Interpretation. New Haven: Yale University. (1967)

[3] Khazin.: Lubāb al-Ta'wōl fì Ma ‘ānī al-Tanzīl Beirūt: Dār al-Kutub al-'Ilmiyyah. (1995)

[4] Palmer, Richard E.: Hermeneutics: Interpretation Theory in Schleirmacher, Dilthey, Heidegger, and Gadamer. Evanston: Northwestern University Press. (1969)

[5] Tabari.: Jāmi 'al-Bayān fì Ta'wīl Ay al-Qur'ān. Beirūt: Mu'assasah al-Risālah. (2000) 